\title{
Playing 'hide and seek' with the Treasury: why do Poles engage in the unofficial labour market?
}

\begin{abstract}
This article is focused on an analysis of the informal labour market in Poland in recent years, based on diverse data sources including the findings of a recent nationwide survey on unregistered work in Poland, conducted in 2009. The author seeks to shed some light on the causes, dynamics and consequences of the existence and development of the informal labour market in Poland. On the one hand, the expansion of different forms of unregistered labour represents a major growth challenge for the newlyemerged market economy in Poland although, on the other, the informal labour market proves to be a kind of shock absorber, enabling the smoother functioning of the economy during economic slowdown.
\end{abstract}

Keywords: unregistered work, informal labour market, shadow economy

\section{Introduction}

Undeclared work is one of the major manifestations of the informal economy. It can be found in many countries of the world, often performed by low-skilled, loweducated individuals as well as immigrants from backward, war-torn and disaster-hit countries, coming - by fair means or foul - either to advanced west European markets, the United States or just more developed countries across the border. However, the extent of unregistered employment and social perceptions of it differ among the countries concerned: in those with a lower level of economic development, the 'shadow economy', with its unofficial labour market, accounts for a large portion of overall economic activity; whereas, in more advanced countries, its presence is smaller and, sometimes, marginal (Mróz, 2002).

Measuring the level of unregistered economic activity is important for a number of reasons (Cichocki and Tyrowicz, 2010). On the one hand, informal economic activity often involves the infringement of the law and entails considerable social and economic costs, such as lower tax revenues for the Treasury, lower social insurance contributions and unfair competition, narrowing the room for the creation of new jobs (with full social benefits) in the official sector. On the other hand, the 'second economy', which is part and parcel of modern economic systems, has the effect of boosting production, stimulating consumer demand and - last, but not least - providing income for jobless people as well as supplementing the wages of employees in the official sector, thus helping to raise the living standards of consumers and households.

A full, objective analysis of undeclared work must, therefore, take into account both the adverse consequences as well as the beneficial ones, at both the macro- and the micro-economic level, and it cannot ignore its social and psychological implications. 
Estimates of undeclared work in Poland in the light of Central Statistical Office research

Over the more than twenty years of systemic transformation in Poland, the informal labour market has cushioned the frictions and tensions in the official sector which have been induced by privatisation, company restructuring and other processes unfolding along the road to a market system. The findings of research by the Polish Central Statistical Office (GUS), as well as of other projects (Bednarski et al, 2008), point to a major importance of undeclared work as a source of untaxed income, supplementing the budgets of Polish consumers and households.

A national survey of the informal labour market, conducted by the GUS in 2009, indicates that the extent of the phenomenon has fallen considerably compared to the position several years previously, even though it nevertheless remains substantial. Over the first nine months of 2009, shadow economy employment ran at 785000 , as against 1317000 between January and September 2004, accounting respectively for $4.9 \%$ and $9.6 \%$ of all people in employment. This might indicate a tangible decline in undeclared employment between 2004 and 2009 but, for a number of reasons, one should be cautious in formulating such far-reaching conclusions (Kałaska, 2010, p. 2).

First, 2006-2008 witnessed a period of rapid economic growth in Poland which prodded companies in the official sector to increase recruitment, thus contributing to a fall in unregistered employment. In 2009, the year of the GUS study, a factor slowing down undeclared work was the 4 billion złoty (some $€ 1$ billion) which employment offices received to spend on proactive forms of countering joblessness. In respect of 2010 , however, it can be surmised that the factors stimulating employment in the informal economy were once again in play.

Second, respondents' declarations on research questionnaires should be viewed with some degree of caution, remembering that some people will not admit to performing undeclared work while others have problems differentiating between official and unofficial jobs. According to the estimates of some experts, between $16 \%$ and $20 \%$ of all those in unofficial employment refuse to acknowledge that this is the case (Szara strefa..., 2010).

And third, those jobs on the informal labour market which are unattractive to Poles have increasingly been taken by foreigners, who are outside the scope of the GUS research.

The number of people in unregistered employment in Poland has been steadily declining since the first such study in 1995, which should be attributed to the country's economic growth during the period of economic transformation and the resulting increased activity among small and medium-sized enterprises (SMEs) in the official sector. In times of prosperity, SMEs have signalled lower demand for unregistered work. A decisively steeper fall in 'unofficial' employee numbers in 2009 can be attributed to the financial and economic crisis which hit most countries (including Poland) in 2008-2009 and which also resulted in subdued activity in the informal economy. It is very likely that, in such circumstances, businesses start by cutting informal employment while - in the expectation of an improved economic climate - they regard sacking those who are formally employed as a last resort. Meanwhile, private individuals turn to 
'unofficial' employees less frequently due to their households' tighter finances and more uncertain prospects for the future.

From the viewpoint of the actors concerned, it is important whether undeclared work is the main activity for the person who performs it, or just a sideline to supplement the family budget. In 2009, it was the main job for 436000 people, or $55.5 \%$ of those in unregistered employment — down from 829 000, or 62.9\%, in 2004 (see Table 1).

Table 1 - Undeclared work as the main and secondary job: numbers and structure of people in informal employment in 2004 and 2009

\begin{tabular}{|l|c|c|c|c|}
\hline \multirow{2}{*}{ Type of undeclared work } & \multicolumn{2}{|c|}{$\mathbf{2 0 0 4}$} & \multicolumn{2}{c|}{$\mathbf{2 0 0 9}$} \\
\cline { 2 - 5 } & $\begin{array}{c}\text { People in } \\
\text { informal } \\
\text { employment } \\
(\mathbf{0 0 0 )}\end{array}$ & $\%$ & $\begin{array}{c}\text { People in } \\
\text { informal } \\
\text { employment } \\
(\mathbf{0 0 0 )}\end{array}$ & $\%$ \\
\hline Undeclared work as main job & 829 & 62.9 & 436 & 55.5 \\
\hline Undeclared work as secondary job & 488 & 37.1 & 349 & 44.5 \\
\hline Total & 1317 & 100 & 785 & 100 \\
\hline
\end{tabular}

Source: author's computations, based on M. Kałaska (2010) Monitoring rynku pracy. Praca nierejestrowana w Polsce w 2009r. Central Statistical Office, Department of Labour. Material for a press conference on 23 December 2010, pp. 7-8.

The figures in Table 1 show that the overall decline in the number of people in informal employment in 2009 compared with 2004, was largely generated by a considerable decrease (of 393000 people, or $47.4 \%$ ) among those for whom informal employment constituted their main job. For those with a secondary job in the informal market, the reduction was lesser, both in absolute and relative terms (respectively, 139000 people; $28.5 \%$ ).

Informal employment in Poland, just as in other countries, is largely short-term, occasional and seasonal. Between January and September 2009, some 22\% (171 000) worked informally for a very short period of up to five days; close to $45 \%$ for up to twenty days; and less than $17 \%$ for 91 days or more. The average time in informal work per year was 48 days, or more than six weeks in the three quarters studied. Compared to the same period in 2004, that actually represented an increase of about $37 \%$; then, the average time spent in informal employment was 35 days (Kałaska, 2010, p. 9).

The seasonal nature of undeclared work in Poland reflects the domination of the informal labour market by gardening/agricultural and construction jobs - types of work in which performance is greatly influenced by the weather conditions. Little wonder, then, that unregistered work was indicated most strongly for the three summer months between July and September. This seasonality is most pronounced in the countryside, whereas in urban areas undeclared work activity is more equally spread over time. 
Factors behind the growth in the Polish informal labour market

Covering various kinds of activity in the informal sector, undeclared work makes a considerable contribution to meeting Polish consumer and household needs. Its widespread character led the Central Statistical Office to start monitoring the informal labour market in 1995. The first comprehensive study of undeclared work was conducted in that year within the regular survey of the population's economic activity, known as BAEL. The next surveys were held in 1998, 2004 and 2009. The findings of the most recent survey are presented in greater detail in this article.

Respondents were asked why they took undeclared work, while the survey sought to identify the extent and intensity of informal work on the supply side (the performance of informal work by those questioned and their households) as well as on the demand side (the unregistered employment of workers by respondents and their households). The questionnaire covered the first nine months of 2009.

Given the problems with finding work on the official labour market, undeclared work plays an important role in the everyday life of Polish consumers and households. The factors prodding Poles to engage in it include (see Table 2):

- a shortage of job openings in the official sector (public and private)

- a difficult financial situation and incomes being insufficient to meet basic requirements

- higher pay opportunities in the unregistered sector

- excessive fiscal burdens: taxes and social insurance contributions.

Table 2 - Why Poles took undeclared work in 2009

\begin{tabular}{|l|c|c|}
\hline Reason & $\begin{array}{c}\text { \%o of total population } \\
\text { aged 15 and over }\end{array}$ & $\begin{array}{c}\text { \% of undeclared job } \\
\text { holders }\end{array}$ \\
\hline Insufficient income & 45.1 & 44.7 \\
\hline A regular job cannot be found & 51.1 & 50.0 \\
\hline $\begin{array}{l}\text { Employer offers higher pay, but without } \\
\text { registration }\end{array}$ & 23.0 & 29.3 \\
\hline Family/personal situation & 6.4 & 6.9 \\
\hline Registration-discouraging taxes & 16.4 & 21.9 \\
\hline High social insurance contribution & 19.8 & 2.8 \\
\hline Resent working regularly for one employer & 1.2 & 7.6 \\
\hline $\begin{array}{l}\text { Registered employment would pose the } \\
\text { threat of loss of benefits }\end{array}$ & 7.6 & \\
\hline
\end{tabular}

Source: author's computations, based on: M. Kałaska (2010) Monitoring rynku pracy. Praca nierejestrowana w Polsce w 2009r. Central Statistical Office, Department of Labour. Material for a press conference on 23 December 2010, p. 3. 
Motives of much lesser force, in respondents' opinions, included the threat of the loss of benefits under registered employment; the family/personal situation; and, as a marginal factor, the resentment of regularly working for one employer.

From the standpoint of an individual consumer/household, the three main goals sought through engagement in undeclared work can be distinguished as follows:

- getting any job, and the related income

- earning higher income than is available from a registered job in the official sector - earning supplementary income.

Breaking the results down by gender identifies no major differences in opinion, with men and women expressing similar sentiments. Problems with finding a regular job were indicated a little more frequently by women than men (52.4\% compared to $49.6 \%$; while men pointed more frequently than women to high social insurance contributions (21.9\% compared to $18.2 \%)$, high taxes (18.5\% compared to $14.8 \%)$ and to the existence of higher pay in unregistered work $(24.9 \%$ compared to $21.6 \%)$ (Kałaska, 2010, pp. 3-4).

Nor were any major differences revealed between the opinions of urban and rural dwellers. Among both groups of respondents, the lack of job opportunities was cited as the prime factor behind turning to informal work (48\% in urban areas; $56.3 \%$ in rural ones); followed by insufficient income, signalled almost equally ( $45.1 \%$ and $45.0 \%$, respectively); and the existence of higher pay from undeclared work $(24.5 \%$ in urban areas; $20.6 \%$ in rural ones). High social insurance contributions were indicated more frequently in towns and cities $(20.4 \%)$ than in rural areas $(18.9 \%)$ (Kałaska, 2010, p. 4).

Among the youngest group of respondents (aged 15-21), who are particularly sensitive to labour market fluctuations, the main factor prodding them into the informal sector was also the inability to find regular work, indicated by the fairly large percentage of $58.2 \%$. As for the other reasons, young people usually cited them less frequently than did the other age groups (except for resentment against working regularly for one employer).

No particularly astonishing conclusions came when viewing undeclared work in accordance with the level of education (see Figure 1). The prime factor behind activity in the informal economy - namely the impossibility of finding regular work - was, understandably, indicated more frequently by less-educated respondents. Those who were educated to a higher level more frequently cited excessive taxes and social insurance contributions as their motives. 
Figure 1 - Opinions about reasons for taking undeclared work, by educational level

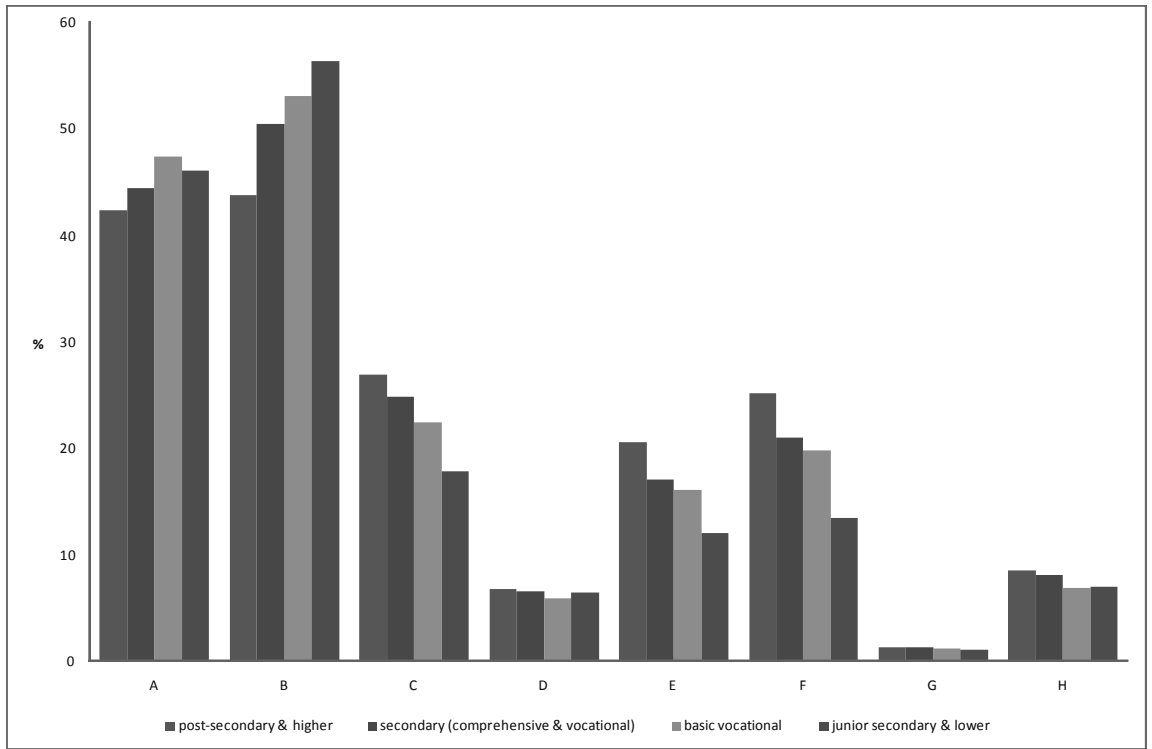

Opinions among the 15 and over age group; figures do not add up to $100 \%$ because a respondent could indicate more than one reason

$\boldsymbol{A}$-Insufficient income; $\boldsymbol{B}-$ A regular job cannot be found;

C-Employer offers higher pay, but without registration;

D-Family/personal situation; $\boldsymbol{E}$ - Registration-discouraging taxes;

$\boldsymbol{F}$-High social insurance contributions; $\boldsymbol{G}$-Resent working regularly for one employer;

$\boldsymbol{H}$-Registered employment would pose the threat of loss of benefits

Source: M. Kałaska (2010).

Types of undeclared work, as related by respondents

It has been indicated by the findings of the GUS research into the subject, conducted in 1995, 1998, 2004 and 2009, as well as by those of a research project commissioned by the Ministry of Labour and Social Policy (Bednarski et al, 2008), that the dominant form of undeclared work is activity in the service sector, especially in construction, and also various kinds of seasonal agricultural and gardening jobs.

In the 2009 survey, across the opinion of the whole body of respondents (i.e. people aged 15 and over), the most frequent types of undeclared work were construction and 
installation renovation and repair; other construction and installation services; children/ elder care; retailing; and household jobs (such as house cleaning). Private teaching (Putkiewicz, 2005), gardening/agricultural jobs and tailoring were also mentioned frequently (Table 3).

Table 3 - The most frequently performed types of undeclared work in 2009 respondents' opinions

\begin{tabular}{|l|c|}
\hline Type of undeclared work & $\mathbf{\%}$ \\
\hline Construction/installation repairs & 47.3 \\
\hline Construction/installation services & 39.3 \\
\hline Children and elder care & 26.8 \\
\hline Retailing & 21.9 \\
\hline Household services (e.g. cleaning) & 21.7 \\
\hline Private teaching & 20.4 \\
\hline Gardening/agricultural jobs & 16.1 \\
\hline Tailoring & 10.7 \\
\hline
\end{tabular}

* Figures do not add up to $100 \%$ because a respondent could indicate more than one type of undeclared work.

Source: author's computations based on: M. Kałaska (2010).

Both men and women earn income from the informal economy, but they differ perceptibly in terms of the undeclared jobs they perform. Some of these jobs tend to be dominated by women - among them, medical/nursing services; hairdressing/cosmetic services; household services; care of other people; tailoring; tourism/catering; private teaching; accounting and legal consultancy services; and interpreting/translating - whereas others are performed primarily by men, especially construction/installation services and repairs; the maintenance of electrical equipment; security; and transportation.

Respondents' place of residence also influences the type of undeclared work performed, reflecting different requirements for services in urban and rural areas. Informalsector jobs indicated most frequently by urban dwellers are: construction/installation renovation and repair; construction/installation services; children/elder care; household services (e.g. cleaning); retailing; and private teaching. Among those living in rural areas, construction/installation renovation and repair was indicated, along with gardening/agricultural jobs and children/elder care, which seems quite understandable given the realities of rural life. 
The importance of undeclared work in Poland: An attempted diagnosis

Informal work constitutes a considerable element of the Polish labour market. Its forms, character and extent are largely determined by the overall business climate and the situation on the domestic labour market, but developments on local labour markets and, to some degree, on those at the European level also play a role (Schneider, 2008). The size of the informal sector not only reflects the overall condition of the economy and the level of registered unemployment but, to some extent, it also results from a structural maladjustment of the demand for labour and its supply (Pickhardt and Shinnick, 2008).

For many Polish households, employment in the informal sector is a significant source of income from which to supplement family budgets. This is especially true where household members have lost employment in the official sector or, as lowlyeducated and professionally unskilled people, have problems finding regular work. Without the income from informal sector activities, making a living would, for many, prove all but impossible. It was demonstrated by a 2007 research study conducted by the Institute for Labour and Social Affairs that more than one-half of respondents $(50.4 \%)$ regard income from the informal sector as an important complement to their household budgets: $36.4 \%$ say they are able to make ends meet thanks to undeclared work; but, for $14 \%$, even the income from undeclared work is insufficient to meet all the current needs of their households (Bednarski et al, 2008, p. 11).

The relatively significant weight of the informal sector in the Polish economy is also influenced by a high (even if decreasing) level of public acceptance. A report by the CASE think tank and SMG/KRC Millward Brown showed that very many Poles approve of informal sector activities, while some $45 \%$ of respondents would themselves readily take undeclared work if such an opportunity presented itself. This translates into a high degree of acceptance and a huge potential for the development of various forms of unregistered employment. More than that, Poles tend to espouse the opinion that many types of undeclared work, especially if performed for household needs, ought not to be taxed. A large segment of respondents (34\%) finds nothing unlawful in undeclared work, while $30 \%$ are prepared to approve of such activities by others - even though tax avoidance is approved by only $17 \%$ (CASE and SMG/KRC Millward Brown, 2008, p. 95).

It therefore comes as no surprise that, in a tough economic climate, households often resort to the purchase or sale of goods and services in the informal sector, where lower prices help the lowest-income consumers and households to make ends meet and enable the more affluent to adjust to the changed realities. It was found in a study conducted by this author in April-May 2009 that Polish consumers and households had taken a series of steps to adjust to the crisis, including buying 'knock-offs' of branded products from vendors in the informal sector (Mróz, 2009).

In conclusion

The findings of the Central Statistical Office's 2009 research into undeclared work point to the informal sector's continually strong presence in Poland. It seems that, in conditions of economic crisis and with wage-earning opportunities shrinking in the 
official sector, consumers and households tend to care less about the shadow economy's negative aspects, focusing instead on meeting their elementary needs and earning additional income through varied forms of informal economic activity (Mróz, 2011).

The additional income earned in the second economy makes it possible for many consumers and households to survive during a tough time on the labour market and, for some others, it is a condition of retaining previously-achieved standards of living and consumption levels (we should recall here the ratchet effect). In a time of crisis, moral dilemmas are put further aside, giving way to pragmatism and hard-headed economic calculus (Błaszczak, 2010; Fandrejewska, 2009).

Micro-economically, this is rational behaviour but, at the macro level, the consequences do present a cause for concern. The labour market must be closely watched to see that the transfer of activity to the informal sector does not grow to excessive proportions and does not lead to a host of undesirable side-effects. Preventing such an outcome will, over the coming years, pose a major challenge for economic policy, which should seek both to make work in the informal sector less attractive and to broaden income-earning opportunities on the official labour market.

\section{References}

Bednarski, M. et al. (Eds.) (2008) Przyczyny pracy nierejestrowanej, jej skala, charakter $i$ skutki społeczne Final research report, Warszawa.

Błaszczak, A (2010) 'Wyciagnąć biznes z szarej strefy’ Rzeczpospolita 21 January.

Cieślak, A and A. Fandrejewska (2009) 'Więcej pracy na czarno' Rzeczpospolita 7 September.

CASE and SMG/KRC Millward Brown (2008) Nierejestrowane zatrudnienie w Polsce. Raport końcowy Warszawa.

CBOS (2009) Reakcje na kryzys gospodarczy. Komunikat z badań Warszawa, February.

Cichocki, S and J. Tyrowicz (2010) 'Źródła zatrudnienia nierejestrowanego w Polsce' Bank i Kredyt 2010, No. 1.

Fandrejewska, A (2010) 'Kryzys zmusza Polaków do przedsiębiorczości’ Rzeczpospolita 25 August.

Kałaska, M (2010) Monitoring rynku pracy. Praca nierejestrowana $w$ Polsce $w$ 2009r. Główny Urząd Statystyczny, Departament Pracy. Materiał na konferencję prasową w dniu 23 grudnia 2010r. (Central Statistical Office, Department of Labour. Material for a press conference on 23 December 2010).

Mróz, B (2002) Gospodarka nieoficjalna w systemie ekonomicznym Szkoła Główna Handlowa: Warszawa.

Mróz, B. (2011) 'Kryzys a szara strefa w polskiej gospodarce' in: M. Bombol (Ed.) Jak żyć w kryzysie? Zachowania polskich konsumentów Szkoła Główna Handlowa: Warszawa. 
Pickhardt, M and E. Shinnick (Eds.) (2008) The Shadow Economy, Corruption and Governance Edward Elgar Publishing: Cheltenham.

Putkiewicz, E (2005) 'Korepetycje - szara strefa edukacji’ Analizy i Opinie 56, December, Instytut Spraw Publicznych.

Schneider, F (2008) The Economics of the Hidden Economy Edward Elgar Publishing: Cheltenham.

Schneider, F and A. T. Kearney (2009) The Shadow Economy in Europe. Using Payment Systems to Combat the Shadow Economy (special report prepared for Visa Europe).

Szara strefa się zmniejszała, ale teraz rośnie (2010) Parkiet 29 December. 